\title{
БЕЗПЕРЕРВНИЙ ПРОФЕСІЙНИЙ РОЗВИТОК ЛІКАРІВ І ПРОВІЗОРІВ - НОВІ ПРИНЦИПИ ПОБУДОВИ СИСТЕМИ
}

\author{
Ю. В. Вороненко, О. П. Мінцер \\ Начіональна медична академія післядипломної освіти імені П. Л. Шупика

\section{NEW PRINCIPLES OF CONSTRUCTION OF CONTINUOUS PROFESSIONAL DEVELOPMENT SYSTEM OF DOCTORS AND PHARMACEUTISTS}

\author{
Yu. V. Voronenko, O. P. Mintser \\ National Medical Academy of Post-Graduate Education by P. L. Shupyk
}

\begin{abstract}
Розглядаються нові технології безперервного навчання лікарів і провізорів на робочому місці. Підкреслюються можливості формування послідовності курсу, вибору його змісту з орієнтацією на індивідуальну траєкторію навчання. Дана технологія дозволяс реалізувати сучасний процес передавання необхідних знань, що пристосовані до професійних особливостей лікарів і провізорів у режимі реального часу.
\end{abstract}

New technologies of doctors' and pharmaceutists' continuous professional development are examined at the workplace. Possibilities of forming of sequence of course, choice of its maintenance are underlined with orientation on the individual trajectory of studies. This technology allows realizing the modern process of necessary knowledge transfer that is adjusted to the professional features of doctors and pharmaceutists in real-time.

Вступ. Необхідність зміни системи медичної освіти зумовлена численними факторами: стрімким зростанням обсягів медичних відомостей; швидкою зміною самого розуміння подій, фактів, явищ; недостатнім часом на передавання необхідних знань; нескінченною розмаїтістю фізіологічних і патологічних станів організму людини.

Впровадження безперервного професійного розвитку (БПР) $є$ таким елементом післядипломної освіти, що найбільш діючий і постійно змінюється.

В останні роки активно розробляється принципово нова технологія формування послідовності курсу, вибору його змісту з орієнтацією на індивідуальну траєкторію навчання. Вона дозволяє автоматизувати процес побудови функції пристосованості до індивідуальних особливостей суб'єктів навчання у режимі реального часу.

Основна частина. В основі технології лежать декілька основних принципів. Перш за все це припущення, що слухач БПР $\epsilon$ центральною фігурою навчального процесу. Відповідно, викладач БПР ставить своїм завданням максимально повне забезпечення слухача навчальними матеріалами шляхом активного використання корпоративної осві- тньої мережі. Отже, створюється постійна система дистанційного передавання знань.

Підкреслимо, що дистанційне навчання (ДН) - універсальна гуманістична форма навчання, котра базується на використанні широкого спектра традиційних, нових інформаційних і телекомунікаційних технологій і технічних засобів, таких, що створюють додаткові умови для слухача, а саме: вільний вибір освітніх дисциплін, що відповідають міжнародним стандартам, діалоговий обмін з викладачем тощо. При цьому процес навчання не залежить від розташування суб' єктів навчання у просторі та часі, а інформаційно-освітнє середовище утворюється сукупністю знань, що акумулюються в спеціальних навчальних курсах і модулях та базуються на засобах обміну інформацією на відстані.

Характерними дидактичними параметрами дистанційного передавання знань $є$ максимальна структуризація навчального тексту; забезпечення інформаційної підтримки; безперервний самоконтроль знань; періодичне проведення коригуючих сесій; забезпечення можливості контактів суб'єктів навчання між собою (єдиний віртуальний навчальний простір); широке використання графіки та зображень.

() Ю. В. Вороненко, О. П. Мінцер 
Важливими умовами ефективності дистанційної освіти є створення єдиної професійної мови та максимально можливе використання медичних стандартів і протоколів; інформатизація охорони здоров'я та, нарешті, спеціальна підготовка викладачів.

Можна констатувати, що основною особливістю такої освіти є надання суб' єктам навчання під час безперервного професійного розвитку можливості самостійно отримувати необхідні знання, перш за все на своєму робочому місці, використовуючи сучасні інформаційні технології. Можливість індивідуалізації навчання є однією з найголовніших переваг використання інформаційних технологій у навчальному процесі.

Отже, другим основним принципом технології $\epsilon$ забезпечення навчання на робочому місці з постійним моніторингом знань і практичних навичок.

Система навчання на робочому місці забезпечує інтерактивний діалог із суб' єктами навчання, контролювання засвоєння та підтримку в отриманні знань в режимі реального часу, вдосконалює стратегію навчання і тестування на основі певного рівня індивідуальних знань, навичок іздібностей суб' єкта навчання.

Зрозуміло, що при навчанні дорослих людей (головний контингент БПР лікарів і провізорів) використовуються особливі дидактичні (андрогогічні) прийоми. Вони включають: відомий зміст навчальних матеріалів; гнучкість; всебічність; прозорість цілей передавання знань; більш виражену адаптивність навчання; обов' язкову наявність навігаційних систем; направленість зворотних зв' язків; зрозумілість понять і мови.

Наступним принципом нової системи БПР слід назвати забезпечення ефективного пошуку необхідноїінформації. Особливої значимостінабуває цей принцип, враховуючи, що забезпечення якості в практичній медицині перш за все орієнтоване на компетенцію лікарів і провізорів. Відповідні знання, наявні в потрібний час у потрібному місці, можуть безпосередньо вплинути на потрібний результат. Проте у країнах $з$ перехідною економікою, де доступ до інформації $€$ досі неповним через низку причин, зазначений процес може бути суттєво утруднений.

Безпосередній обмін знаннями та їх оцінювання між колегами у достатньому обсязі гальмуються значними відстанями та повільною системою громадського транспорту. Паперові засоби інформації, такі, як медична література, наукові видання, $\epsilon$ недостатніми через обмеженість фінансових ресурсів і механізмів розповсюдження. Бібліотеки надають обме- жений вибір медичної літератури, що не відображає повний спектр сучасних і визнаних на міжнародному рівні знань. Сучасні розробки в медичній науці, що обговорюються у закордонних наукових журналах, впливають на клінічну практику та сприяють змінам у клінічних настановах, однак можуть не доходити до уваги частки медичної спільноти, особливо до тих, які працюють поза межами міських центрів.

Підкреслимо, що однією з перешкод для розвитку та модернізації системи охорони здоров’ я в Україні $\epsilon$ недостатня кількість засобів комунікації, а також доступу до найсучаснішої доказової інформації. Структурні чинники підсилюють нерівність між міськими центрами і віддаленими районними закладами охорони здоров'я первинного та вторинного рівнів. Спеціалізовані знання акумулюються в закладах національного рівня, тому медичним працівникам, які працюють на периферії, часом важко отримати до них доступ.

Отже, процес безперервної медичної освіти працівників галузі охорони здоров'я сильно ускладнений внаслідок великих відстаней і повільної системи передавання інформації.

Аналізуючи характер медичної інформації, слід зауважити, що структуровані дані становлять усього 20 \% загального обсягу, а їх нарощування не $є$ прогнозованим, тоді як неструктурована інформація становить $80 \%$ загального обсягу відомостей. Щорічно спостерігається двократне збільшення обсягу відомостей. Навіть фахівці зуправління знаннями витрачають $35 \%$ робочого часу на пошук інформації, а $40 \%$ них важко знайти необхідну для роботи інформацію навіть в Інтернет-мережі.

Велика частина літературних джерел фокусується на якісних особливостях методології та заключному резюме досліджень. Дискусії відносно характеру досліджень присутні нечасто. Це залишає невеликий простір для обговорень і проблем індивідуалізації клінічних рекомендацій.

Ще більш важливим $€$ те, що концептуальні питання організації досліджень і впровадження наслідків дослідних робіт також залишаються поза матеріалами статей, підручників, посібників. Намагання ідентифікувати різні варіанти (моделі) тієї ж самої події нерідко призводять до помилок або поверхневих висновків.

Коректне відстеження потоку інформації у навчальній і науковій літературі ускладнюється наявністю когнітивної та інших видів асиметрій у завданнях передавання знань (вікова, гендерна, соціальна 
тощо). Найважливішою вважається когнітивна асиметрія, що підсумовує результати дисбалансу в основних складових сфери знань (доступ до інформації, освіта, наукові дослідження, культурне та мовне різноманіття), і та, що стає справжнім викликом цілям побудови суспільства знань.

Зрозуміло, що на будь-якому крупному пошуковому сервері (Яндекс, Рамблер, Google) надається можливість пошуку. В межах одного сайту подаються всі сторінки, релевантні поставленому питанню. Це стандартна опція крупних сайтів. Алгоритми ранжирування результатів пошуку в межах одного сайту i пошуку в Інтернеті однакові: спочатку подаються найбільш релевантні сторінки, нижче - менш релевантні й так далі.

Отже, посилання в результатах пошуку сортуються за релевантністю, що визначається як “відповідність знайденого документа тексту запиту”. В більшості випадків це абсолютно недостатньо. Неможливість сформулювати в стандартному вигляді запитання, велика кількість синонімів, величезна кількість форматів подавання результуючої інформації не дозволяють отримати не тільки повну, але і точну інформацію. Лише в останні роки з' явилися нові технології пошуку інформації. Вони пов'язані з використанням контент-аналізу, коллокейт-аналізу, Z-score аналізу тощо.

Контент-аналіз - вербальний аналіз або аналіз змісту - стандартна методика досліджень, предметом якої є зміст текстових масивів (у тому числі продуктів комунікативної кореспонденції). У вітчизняній літературі контент-аналіз визначається як кількісний аналіз текстів і текстових масивів 3 метою наступної змістовної інтерпретації числових виявлених закономірностей. Він застосовується при вивченні джерел, інваріантних за структурою чи змістом, але 3 несистематизованим, безладно організованим текстовим матеріалом. Сенс контент-аналізу як дослідницького методу визначається як перехід від різноманіття текстового матеріалу до абстрактної моделі змісту тексту.

В останні роки отримують розвиток й інші методи вдосконалення пошуку потрібної інформації, зокрема коллокейт-аналіз. Він являє собою синтетичну класифікацію, впорядкування, зіставлення слів або інших компонентів, перш за все тих, що зустрічаються спільно. Іншими словами, він уособлює метод концептуалізації та розуміння вербальної інформації.

Розроблення методу проводили у 1995 - 2002 pp. (Lincoln, 2000; Doniger, 1998; Gubrium and Holstein,
1997; Miles and Hubberman, 1994; Patton, 2001). У результаті він дозволяє обгрунтувати шлях від численних описових робіт до методологічно грамотної побудови взаємопов' язаних конструкцій адекватно тим, що описують існуюче положення в комунікативних і дослідницьких процесах.

У його основі лежить виділення понять і термінів, що зустрічаються в поєднанні з обраним показником частіше, ніж інші. При цьому зіставлення здійснюється в соціально-частотному, професійному та частотно-проблемному діапазонах. Враховуються й ідіоматичні вирази.

Отже, плануючи нову й ефективну систему пошуку навчальної та наукової інформації для післядипломної медичної освіти, слід забезпечити інтуїтивнозрозумілий інтерфейс; високу ефективність пошуку; розвиток пошукових навичок користувачів; уніфікований інтерфейс (при пошуку на персональному комп'ютері, в корпоративній мережі й Web-pecypcax); високу швидкість роботи, простоту настроювання, безмежне масштабування; широкий спектр функціональних можливостей; сервіс-орієнтовану архітектуру; високу надійність; розмежування доступу; низьку вартість супроводу.

Пошукова система повинна бути корисною при роботі на персональному комп'ютері, для пошуку в загальних мережевих директоріях, корпоративних інформаційних ресурсах, а також для побудови систем високої доступності.

Вкрай важливими характеристиками для користування повинні бути універсальний і повний інтерфейс доступу до будь-якої інформації; забезпечення доступу до інформації незалежно від форматів документів та їх розташування; сумісне з більшістю сховищ даних; безпечний процес пошуку; підтримка засобів розмежування доступу.

У новій технології забезпечується використання сучасних систем навігації, оброблення та каталогізації даних для більш ефективного застосування величезних інформаційних ресурсів Інтернету, електронних бібліотек, баз даних і знань. При цьому нова система передачі знань має інтуїтивно зрозумілий інструментарій, що дозволяє викладачеві створювати, додавати, змінювати навчальний матеріал, курси, методи тестування та оцінювання суб' єктів навчання, аналізувати результати навчання.

Серед інших принципів нової системи БПР слід назвати: впровадження єдиного освітнього простору (четвертий принцип); постійний комп'ютерний самоконтроль знань (п'ятий принцип); дистанційний рубіж- 
ний і вихідний контролі ( шостий принцип); інформаційну децентралізацію освіти (сьомий принцип); впровадження логіки компетенцій (восьмий принцип); створення та впровадження індивідуального портфоліо (дев'ятий принцип). Їх обговорення стане предметом окремої статті.

Слід підкреслити, що розроблення електронних засобів навчання (е-освіта) в першу чергу пов'язане 3 процесами надання інформації відповідної форми чи iї пакування. Аналогічна операція може виконуватись і над знаннями. Тому різниця між знанням та інформацією повинна враховувати "надання форми" знанням упроцесіперетворення його в інформацію (“інформаціоналізація" знань).

Резюмуючи викладене, можна висловити думку (до речі, збігається з висновками деяких експертів), що відкрите та дистанційне навчання може цілком і остаточно витиснути традиційну школу як місце от-

\section{Лiтература}

1. Григорьев С. И. Основы современной социологии : учебное пособие / С. И. Григорьев, Ю. Е. Растов. - Барнаул : Издательство Алтайского государственного университета, 2001.-250 c.

2. Социологическая энциклопедия / под общ. ред. А. Н. Данилова. - Минск : Беларуская энцыклапедыя, 2003. $-382 \mathrm{c}$.

3. Федотова Л. Н. Анализ содержания - социологический метод изучения средств массовой коммуникации / Л. Н. Федотова. - М. : Институг социологии РАН, 2001. - 202 с. римання знань. Викладачі повинні тільки спрямовувати процес навчання, а кафедри будуть лише місцем інтеграції знань і розроблення нових технологій їх передавання.

Висновки: 1. Запропонована нова технологія передавання знань у системі післядипломної медичної освіти лікарів і провізорів. Її основу складають 9 принципів: індивідуалізація освіти; навчання на робочому місці; ефективний пошук професійної інформації; впровадження єдиного освітнього простору; постійний комп' ютерний самоконтроль знань; дистанційний рубіжний і вихідний контролі; інформаційна децентралізація освіти; впровадження логіки компетенцій; створення та впровадження індивідуального портфоліо.

2. Потребують невідкладного розвитку технології постійного моніторингу знань і практичних навичок.

3. Надзвичайно актуальною стає проблема підготовки викладачів.

4. Busari J. Education Doctors in the Clinical Workplace: Unraveling the Process of Teaching and Learning in the Medical Resident as Teacher / J. Busari, A. Arnold. - Pecypc : http://www.jpgmonline.com. - PP: 46202.57.165.

5. Learning Opportunities for Nurses and Care Assistants in Care Homes. J. of Workplace Learning. - Vol.23, Issue 1. 2011.-P. 6-32. 